\title{
マテリアルズ・インフォマティクスによる全固体電池材料の最適化
}

\author{
中山 将伸 ${ }^{\mathrm{a}, \mathrm{b}}$, 原田 真帆 ${ }^{\mathrm{a}}$, 武田はやみ ${ }^{\mathrm{a}, \mathrm{b}}$
}

a 名古屋工業大学 大学院工学研究科 ( ⿳ 466-8555 愛知県名古屋市昭和区御器所町)

$\mathrm{b}$ 京都大学 触媒電池元素戦略拠点 (ESICB) ( $=$ 615-8245 京都府京都市西京区御陵大原 1-30)

\section{Materials Optimization for All-solid-state Li Secondary Batteries by Materials Informatics}

\begin{abstract}
Masanobu NAKAYAMA ${ }^{a, b}$, Maho HARADA a and Hayami TAKEDA ${ }^{\text {a,b }}$
${ }^{a}$ Department of Life Science and Applied Chemistry, Nagoya Institute of Technology (Gokiso-cho, Showa-ku, Nagoya-shi, Aichi 466$8555)$

${ }^{\mathrm{b}}$ Elements Strategy Initiative for Catalysts and Batteries, Kyoto University (1-30, Goryo-Ohara, Nishikyo-ku, Kyoto-shi, Kyoto 615$8245)$
\end{abstract}

Keywords : All-solid-state Li Secondary Batteries, Materials Informatics, Bayes Optimization

\section{1. 緒 言}

人工知能「AI」が注目されている。 $\mathrm{AI}$ 技術そのものは古 くから知られていたが, インターネットなどを通じて簡便か つ安価に得られる膨大なビッグデータと, コンピューターの 高性能化, そして機械学習と呼ばれる情報学(インフォマティ クス) 技術の深化によって, 人類は今まさに科学の「第 4 の パラダイムシフト」にあるといわれている1)。

材料の, 研究・開発・産業の世界においても上述の AI 技 術と連携した「マテリアルズ・インフォマティクス (Materials Informatics) ${ }^{2)} 」$ と呼ばれる新分野が形成しつつある。具体例 として，2011 年 6 月に米国オバマ大統領(当時)は材料産業 の研究開発期間を短縮することが産業競争力において決定的 であると講演し，国家プロジェクトとして Materials Genome Initiative (MGI) がスタートしている。この講演を起点として, Materials Informaticsへの注目は進み, 例えば学術論文の被引 用数を例にすると, 近年では指数関数的に増大していること が図 1 のグラフよりわかる。

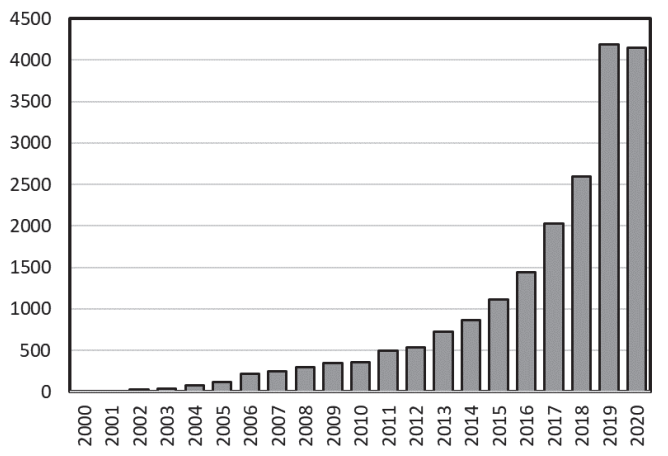

図 1 Materials informatics をキーワード検索した学術論文の被引用 数の推移

(Clarivate Analysis, Web of Science にて調查(2020 年 11 月時点))
一方で, Materials Informatics という用語が定着してから既 に約 10 年が経過しようという現在, 今後はより産業に直結 するような実際的・実務的な活用事例とその成果が求められ る。成果の形態は複数考えられるが, やはり優れた機能をも つ新材料の発見は, 多くの関係者が待望する直接的な成果で あるといえる。しかし, 現時点で著者の知る限りでは, 既存 の材料の性能を大きく凌駕するような新材料が, Materials Informatics あるいはその関連技術により発見され工業的に応 用されたという決定的な事例は非常に少ないと思われる。こ の理由の一つとして, Materials Informatics の多くの研究事例 が, 材料シミュレーションとインフォマティクスの連携的な 研究にあると考えられる。新材料の発見には, 実験的な評価 が欠かせないが, 実験とインフォマティクス研究の連携的研 究の事例は少ない。このような観点から, Materials Informatics が産業応用に直結するための一つの方向・課題が, 実験との連携にあると考えられる。

図 2 は著者らが考える現状の材料産業における研究開発の スキームである。第一のステップ(Step1) は, 新しいコンセ プトに基づく新機能材料の創出である。例えば, 蓄電池の世 界では Goodenough 博士らが 1980 年に層状岩塩型 $\mathrm{LiCoO}_{2}$ 正 極材料を発見 ${ }^{3)}$ しているが, この材料は 1991 年のリチウム イオン電池の商品化に際に実用に供せられた材料である。 2019 年にノーベル化学賞に結び付いていることから, 読者 の記憶にも新しいと思われる。この過程は，一言でいえば優 れた研究者のセレンディピティに依存する箇所である。実用 化に結び付く材料が発見されたのちは, 組成や合成プロセス 改善による試行錯誤プロセスで続くと考えられる(Step2)。 特に元素置換やそれに伴う久陷導入は, 材料物性をある程度 改善すると期待されるが, 置換元素種やドープ量の選定で幅 広い選択肢が発生する。そのため, 組成の選定, 物性の計測, フィードバックによる新たな組成選定の試行錯誤ルーチンと なり, 最適組成に至るまでには長い時間が必要になる。先述 


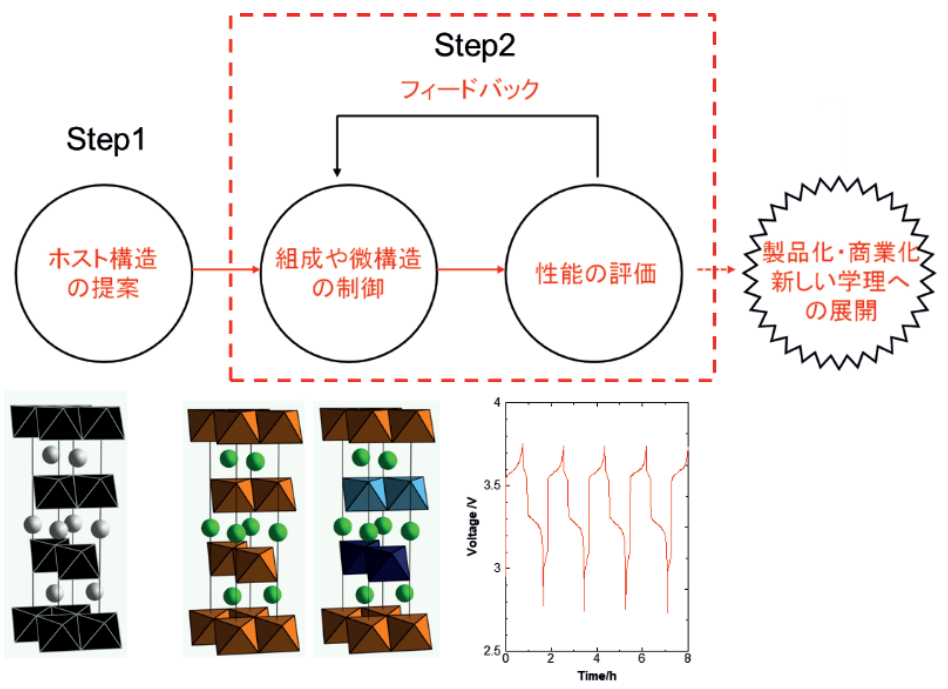

図 2 新材料に関する研究・開発フェーズから製品化への流れ Step1 は骨格となる機能性材料の提案, Step2 は組成や組織の制御に おける試行錯誤を表している。

したように Goodenough 博士らが $\mathrm{LiCoO}_{2}$ を発見してから現 在で約 40 年が経過しているが, 近年の電池正極材料のトレ ンドの一つとして $\mathrm{LiCoO}_{2}$ 構造そのままに, Co を高濃度 $\mathrm{Ni}$ で置換したようなハイニッケル系材料が精力的な研究開発の 対象になっていることを考えると，置換による組成最適化は 非常に時間コストのかかる開発過程であるといえる。以上， (1) コンセプト・骨格として全く新しい材料の創出と (2) 組成 やプロセスの最適化による材料機能最適化の 2 つ研究開発 フェーズがあることを述べた。本稿では，主に後者の組成最 適化実験について, Bayes 最適化 ${ }^{4)}$ と呼ばれるインフォマ ティクスアプローチ用いて最適化を効率化する試みを紹介す る。なお，（1）については，網羅計算やインフォマティクス を適用した固体電解質材料探索の実例は, 近著の解説記事に て紹介している ${ }^{5)}$ 。

\section{2. 固体電解質材料 $\mathrm{LiZr}_{2}\left(\mathbf{P O}_{4}\right)_{3}$}

現在のリチウムイオン電池は, 電解質にエーテル系の有機 電解液を用いており, 爆発・燃焼による安全リスクを抱えて いる。このようなリスクは，電気自動車車載電池のような大 型電池になるほど大きくなることから, 有機電解液を廃し, リチウムイオン導電性のセラミックス材料 (固体電解質)に置 き換え全固体電池を実現しようとする試みが 1980 年代から 議論されていた。固体電解質が酸化物セラミックスであれば, 燃焼に対するリスクがなくなる。さらに現行の炭素負極の容 量に対して理論上 10 倍を超えるリチウム金属負極は，これ まで有機電解液との燃焼リスクの関連で忌避されてきたが, 固体電解質を採用することで負極に用いることが可能になれ ば，安全性とともに電池容量の大幅な向上も期待できる。以 上の観点で電気自動車用車載電池として固体電解質材料の開 発が加速している。

全固体電池のための固体電解質に求められる特性は, 多岐 にわたる。（1)高いリチウムイオン導電特性(粒内・粒界), (2) 十分な電子伝導に対する絶縁性，（3）十分な機械的強度，(4) 正極負極に対する酸化還元耐性，（5）電極電解質における高
いイオン交換反応速度などがあげられる。このような諸特性 のうち，(4)において還元耐性に優れ，金属 Li を負極に用い ることができる酸化物材料が特に注目されている。負極金属 Li は電位が最も低く容量が非常に大きいため, 採用すれば エネルギー密度を一気に大きくすることが可能である。しか し， セラミックス材料といえど負極 $\mathrm{Li}$ と接触すると還元反 応してしまう材料が多く金属 Li 電極を用いるための障害に なっていた。近年では比較的リチウムイオン導電性が高く, 金属 $\mathrm{Li}$ と反応しないガーネット型 $\mathrm{Li}_{7} \mathrm{La}_{3} \mathrm{Zr}_{2} \mathrm{O}_{12}$ 材料が注目さ れており, 精力的な研究がなされている ${ }^{6)}$ 。最近, NASICON 型 $\mathrm{LiZr}_{2}\left(\mathrm{PO}_{4}\right)_{3}$ 材料 (以降 LZP と略す) が, Goodenough 博士 らのグループで提案され，実際に金属 $\mathrm{Li}$ 電極を用いた電池 の製作評価も行われている7),8)。われわれのグループでも, 当該材料についての金属 Li に対する安定性やイオン伝導性 について，第一原理計算と実験に基づいて評価を行った ${ }^{9)}$ 。 その結果, LZP 材料は Li 金属に対して熱力学的には安定で はなく, 表 1 に示すように電位の変化とともに段階的に分解 反応が進行することが分かった。ただし，分解生成物である $\mathrm{Li}_{8} \mathrm{ZrO}_{8}$ と $\mathrm{Li}_{3} \mathrm{P}$ が生成すると, それらの化合物は金属 $\mathrm{Li}$ に対 して不活性であるため反応初期に表面をコートし金属 Li 電 極を用いた全固体電池でも安定して動作すると考えられる。

表 1 第一原理計算によって計算された各電位領域における $\mathrm{LiZr}_{2}$ $\left(\mathrm{PO}_{4}\right)_{3}$ と金属 $\mathrm{Li}$ の分解反応 ${ }^{9}$ (出版社より許可を得て再掲)

\begin{tabular}{ll}
\hline decomposition reaction & voltage [V] \\
\hline $4 \mathrm{LiZr}_{2}\left(\mathrm{PO}_{4}\right)_{3}+5 \mathrm{Li} \rightarrow \mathrm{P}+3 \mathrm{Li}_{3} \mathrm{PO}_{4}+4 \mathrm{Zr}_{2} \mathrm{P}_{2} \mathrm{O}_{9}$ & $2.15-2.20$ \\
\hline $\mathrm{LiZr}_{2}\left(\mathrm{PO}_{4}\right)_{3}+5 \mathrm{Li} \rightarrow \mathrm{P}+2 \mathrm{Li}_{3} \mathrm{PO}_{4}+2 \mathrm{ZrO}_{2}$ & $2.10-2.15$ \\
\hline $5 \mathrm{LiZr}_{2}\left(\mathrm{PO}_{4}\right)_{3}+28 \mathrm{Li} \rightarrow 2 \mathrm{ZrP}_{2}+11 \mathrm{Li}_{3} \mathrm{PO}_{4}+8 \mathrm{ZrO}_{2}$ & $1.83-2.10$ \\
\hline $11 \mathrm{LiZr}_{2}\left(\mathrm{PO}_{4}\right)_{3}+84 \mathrm{Li} \rightarrow 6 \mathrm{ZrP}_{2}+21 \mathrm{Li}_{3} \mathrm{PO}_{4}+16 \mathrm{Li}_{2} \mathrm{ZrO}_{3}$ & $1.73-1.83$ \\
\hline $23 \mathrm{LiZr}_{2}\left(\mathrm{PO}_{4}\right)_{3}+196 \mathrm{Li} \rightarrow 14 \mathrm{ZrP}_{2}+41 \mathrm{Li}_{3} \mathrm{PO}_{4}+16 \mathrm{Li}_{6} \mathrm{Zr}_{2} \mathrm{O}_{7}$ & $1.37-1.73$ \\
\hline $4 \mathrm{LiZr}_{2}\left(\mathrm{PO}_{4}\right)_{3}+56 \mathrm{Li} \rightarrow 7 \mathrm{Li}_{3} \mathrm{P}+5 \mathrm{Li}_{3} \mathrm{PO}_{4}+4 \mathrm{Li}_{6} \mathrm{Zr}_{2} \mathrm{O}_{7}$ & $1.10-1.37$ \\
\hline $\mathrm{LiZr}_{2}\left(\mathrm{PO}_{4}\right)_{3}+24 \mathrm{Li} \rightarrow 3 \mathrm{Li}_{3} \mathrm{P}+2 \mathrm{Li}_{8} \mathrm{ZrO}_{6}$ & $1.02-1.10$ \\
\hline $7 \mathrm{LiZr}_{2}\left(\mathrm{PO}_{4}\right)_{3}+197 \mathrm{Li} \rightarrow 12 \mathrm{Li}_{3} \mathrm{P}+84 \mathrm{Li}_{2} \mathrm{O}+\mathrm{Zr}_{14} \mathrm{P}_{9}$ & $0.95-1.02$ \\
\hline $7 \mathrm{LiZr}_{2}\left(\mathrm{PO}_{4}\right)_{3}+200 \mathrm{Li} \rightarrow 13 \mathrm{Li}_{3} \mathrm{P}+84 \mathrm{Li}_{2} \mathrm{O}+2 \mathrm{Zr}_{7} \mathrm{P}_{4}$ & $0.00-0.95$ \\
\hline
\end{tabular}

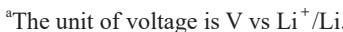


一方 LZP に置いて, リチウムイオンが一つ隣のサイトにホッ ピングすることで，近接するリチウムイオンが押し出され， その過程が連鎖することで一度に複数のリチウムイオンが伝 導する協奏的伝導機構により高いリチウムイオン電導特性が 得られることも分かった。このことから，格子間にリチウム イオンを過剩にドープすることでリチウムイオンの押し出し メカニズムによる伝導を促進することが可能であり，高いリ チウムイオン導電性が期待できる。実際に Goodenough 博士 らのグループでは $\mathrm{Ca}^{2+}$ や $\mathrm{Y}^{3+}$ のようなイオンを $\mathrm{Zr}^{4+}$ に置換 し，格子間 $\mathrm{Li}$ を導入することでイオン導電性の向上に成功 している。一方で, リチウムイオン導電性は置換量の増加に 対して単調増加するわけではなく, 最適量が存在することも 知られている。第一原理計算による結果では, ドーパントで ある低価数 $\mathrm{Ca}^{2+}$ や $\mathrm{Y}^{3+}$ にリチウムイオンがトラップされる ことが原因であることを確認している ${ }^{10), 11) 。 ~}$

以上のように LZP 材料は将来の全固体電池材料として魅 力的な候補材料の一つであるが, リチウムイオン導電性の改 善が必要であり，組成やプロセス条件の最適化が必要である。 たとえば，先述した $\mathrm{Ca}^{2+}$ 置換について考えると，その置換 量を 10 通り検討するとなると, 当然 10 回も実験的評価を行 わなければならない。これに $\mathrm{Y}^{3+}$ をコドープするような検討 をした場合，探索空間は $10^{2}=100$ 通りとなる。更に合成温 度を 10 通り変えるという因子を増やせば, $10^{3}=1000$ 通りと なる。このように, 組成やプロセスの制御因子を多少増やす だけで，指数関数的に探索空間が増えることがわかる。一般 論として，膨大な組成・プロセスパラメーターを網羅的に調 査することは不可能であるため, 一般的には探索法は, 材料 学・電気化学などの知識と経験を有した研究者の合理的直観 で探索することになる。具体的には，（1）今あるデー夕や知 識に基づいて, 結晶構造や物性を予測し, 次に調査すべき材 料を提案する。(2) 提案された組成・プロセスに従って実際 に実験で材料を作成，評価検をする。（3）新たに付け加わっ たデータをフィードバックしたうえで，次に実験すべき材料 を提案する。以降，（2）と(3)のステップを交互に繰り返して, 最も性能の良い材料を発見する。このような提案と検証の
ループを繰り返すことになるが，（1）または(3)のステップで できるだけ少ないステップ数で最もよい材料を見つけられる ような人材こそが, 腕の良い研究者となる。AI を用いて最 も優れた材料を探すという試みは，この(1)または (3)のス テップを，人間ではなく AI が担当することになる。

\section{Bayes 最適化}

上述したように，最適組成を探索するために $\mathrm{AI}$ を用いる と直感的に記載したが, 本稿で紹介する例では「AI」=「Bayes 統計を用いた最適化(Bayes 最適化)」となる。従来の統計学 では，母集団から抽出した標本を用いて統計的予測をする場 合(つまり抜き取り検査をする際), 標本はランダムに選択し なければ統計的技術を適用できないという考え方がある(頻 度主義)。一方で, ベイズ主義と呼ばれる統計では, 既知の 知識・経験に基づくバイアスに従って標本を抽出しても, ベ イズの定理に基づいて統計的取り扱いができる。これは，前 節の後半で述べたように, 材料研究者(人間)がこれまでに得 られたデータを分析して次のサンプルの選定調査に役立てる というフィードバック過程を応用数学で取り扱い可能である ことの前提となる。

このようなべイズ統計の考え方に加えて, 具体的な探索方 針を規定する PI 戦略や EI 戦略と呼ばれるアルゴリズムがあ る ${ }^{12)}$ 。著者にはこのアルゴリズムの数学的詳細について解 説する力量はないので, 以下に大雑把な実例を挙げて説明を 試みたい。例として図 3 に示すように，2つの組成量 $\mathrm{x} ， \mathrm{y}$ の 值を変化させて最も優れた物性を持つ材料を探索することを 考える。全くデータがない場合には, 多くの研究者は端の点 から順番に調査するよりも，例えば図 3 (1)に示すように, なるべく間隔をあけて数点抽出 (この場合 4 点) し物性評価を 行う(良・可・悪で表記)。この結果に得られた標本の良否が 得られる。得られた結果から, 物性分布の推測を行うが, 図 の場合では，左下に行けば行くほど性能がよくなるという予 測ができよう。このような予測に基づいて, 最も性能のよさ そうな点(図 3 (2)の A 点)を次の調査点としようというのが 「搾取 (exploitation)」と呼ばれる。一方で, 評価した標本数

\section{(1)}

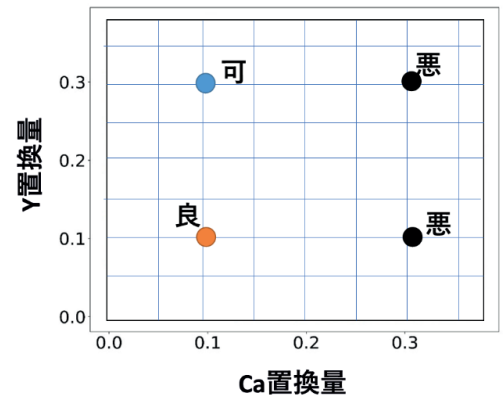

(2)

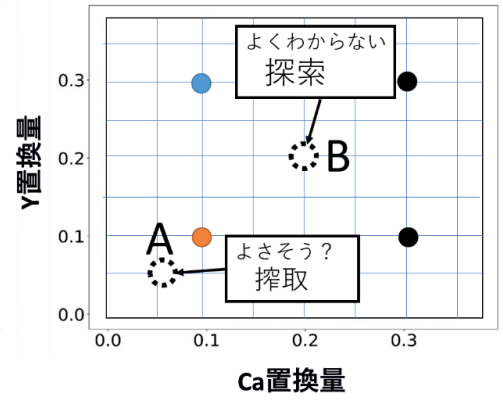

図 3 NASICON 型 $\mathrm{LiZr}_{2}\left(\mathrm{PO}_{4}\right)_{3}$ 材料に $\mathrm{Ca} / \mathrm{Y}$ をコドープする場合の探索範囲と 探索の一例

(1) 探索組成範囲の中からできるだけ均等に 4 点を選び性能を評価。（性 能評価の結果は良・可・悪で示してある) (2)（1）の結果を受けて, 次に評 価する材料の抽出を行う過程。A 点は, より性能の向上しそうな組成を 優先的に選んだ場合(搾取という)， B 点は，より俯瞰的に組成に対する 性能の増減の傾向を把握するために選んだ場合(探索という)に対応する。 
が少ないことから, 既知の評価点から遠く離れた場所につい ては統計的予測が不明瞭になりがちな箇所が発生する。この ように予測が不明瞭な場所 (図 3 (2)のB 点)を優先して調査 しょうとすることを「探索(exploration)」と呼ぶ。結果から 言えば, ベイズ最適化でよく用いられる EI 戦略とは,「搾取」 と「探索」を何らかの指標で数值化し(獲得関数と呼ばれる), 探索あるいは搾取のどちらを優先するか使い分けながら次の サンプルを選ぶアルゴリズムである。なお,「竹取」と「探索」 のどちらを優先するかという基準は,いわば人間的な性格(た とえるなら「せっかち(=搾取)」と「慎重 $(=$ 探索 $) 」)$ を反映 する基準に相当し，ハイパーパラメターと呼ばれている。実 際に，ハイパーパラメターは，ユーザーが与えなければなら ない基準值である(ソフトウェアーの中には自動的に決定す るものがある)。また「搾取」と「探索」に基づく EI 戦略以 外にも, いくつかのアルゴリズムがありその選択もユーザー の判断に委ねられる。

\section{4. 固体電解質材料 $\mathbf{L Z P}$ の $\mathrm{Ca}^{2+} / \mathbf{Y}^{3+}$ のコドープと 特性評価}

NASICON 型材料では Li を格子間サイトに導入し Li 過剩不 定比組成にするとイオン導電性が高くなることが知られてい る。このような観点から, 例えば $\mathrm{Zr}^{4+}$ サイトに低価数のイ オンである $\mathrm{Ca}^{2+}$ や $\mathrm{Y}^{3+}$ を導入することで電荷保証により $\mathrm{Li}$ 過 剩にしてイオン導電性を高める試みがなされてきた ${ }^{10), 11)}$ 。し かし多くの研究では, 先述したように置換種を増やすことで 探索空間が指数関数的に増大することから， 単元素を置換 · ドープすることが多い。一方で，2種の元素を同時にドープ (コドープ)し，物性や構造を丹念に調査することで，ドーパ ントの役割がより明瞭になることもある。図 4 は, $\mathrm{Ca}^{2+}$ と

\section{(a)}

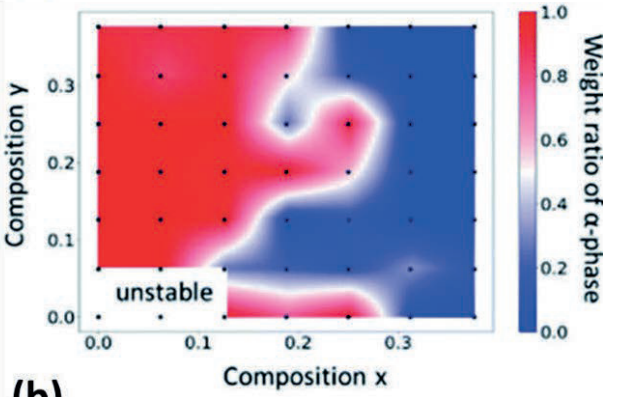

(b)

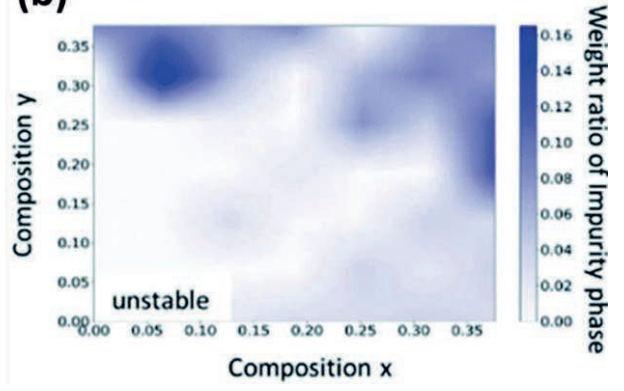

图 $4 \mathrm{Li}_{1+\mathrm{x}+2 \mathrm{y}} \mathrm{Zr}_{2-\mathrm{x}-\mathrm{y}} \mathrm{Y}_{\mathrm{x}} \mathrm{Ca}_{\mathrm{y}}\left(\mathrm{PO}_{4}\right)_{3}$ 材料について XRD 測 定によって得られた (a) 合成した材料に含まれ る $\alpha$ 相 (NASICON 相)の割合と (b) 不純物の重量 分率の分布 ${ }^{13)}$ (出版社より許可を得て掲載)
$\mathrm{Y}^{3+}$ のドープ量を系統的に変化させたときの XRD 構造解析

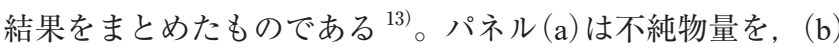
は赤が $\alpha$ 相 (NASICON 相), 青が $\beta$ 相 (単斜晶相)の分布を示し ている。ドープ量が多くなるほどに不純物相が現れるのは予 測通りの結果である。一方, $\mathrm{Ca}^{2+}$ ドープに対しては $\alpha$ 相が安 定だが $\mathrm{Y}^{3+}$ ドープに対しては $\beta$ 相が安定になる傾向にある。

NASICON 型となる $\alpha$ 相は高いイオン導電性を有すると考え られていることから, $\mathrm{Ca}^{2+}$ と $\mathrm{Y}^{3+}$ の置換量が同等あるいは $\mathrm{Ca}^{2+}$ が多くなるような領域で高イオン導電相となるように考 えられる。また, 図 5 は焼結体の相対密度を示している。図 から明らかなように $\mathrm{Ca}^{2+}$ は焼結助剤として有効であり，一 定量以上の $\mathrm{Ca}^{2+}$ を導入することで $\mathrm{Y}^{3+}$ 量にかかわりなく相 対密度が向上することが確認できる。より詳細にデー夕を見 ると $\mathrm{Y}$ と $\mathrm{Ca}$ のドープ量が等しい箇所で焼結密度は向上する 傾向にあるが，その理由は不明である。焼結度の向上は，材 料の機械的強度を向上させるだけではなく，一般的には粒界 抵抗を低減するため，材料のイオン導電性向上に有効である。 図 4 と図 5 の情報は, 上述したように高イオン導電性材料を 設計するために有用な知見となりうるが，これらのデータを 参照できるということは，実際にすべてのサンプルを合成し なければならないという「効率」の問題がある。

図 6 は $30{ }^{\circ} \mathrm{C}$ におけるリチウムイオン伝導度とアレニウス プロットから得られた活性化エネルギーの分布である。イオ ン伝導度は, バルクと呼ばれる粒子内体積抵抗と, 粒界とよ ばれる粒子間の界面抵抗の和で与えられている。複素イン ピーダンスプロット法と呼ばれる実験法では, 原理的に抵抗 を分離することが可能であるが，焼結密度が低いサンプルな どでは分離が困難になる傾向があるため, 統一してバルクと 粒界の抵抗和を取り扱った。各々のサンプルの焼結密度はプ ロセスを工夫することで向上することは可能であるが，イオ ン導電性に与える影響が複雑になることと，なにより多数の サンプルを扱っていることが研究リソース上の制約となるた め, 個別のプロセス最適化の検討は実施されていない。図か

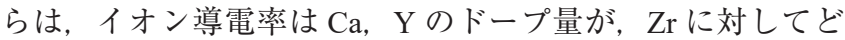
ちらも 0.13 程度 (モル比)の時, 導電率は高くなることが分 かった。最適イオン伝導度は単元素ドープの最適值に比べる と約 5 倍程度向上していることから，コドープが有効である ことが分かった。一方, 活性化エネルギーは值が低いほど望

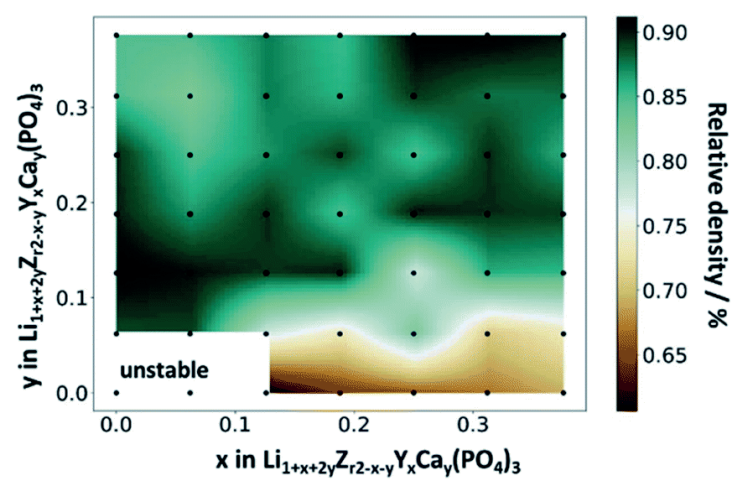

図 $5 \mathrm{Li}_{1+\mathrm{x}+2 \mathrm{y}} \mathrm{Zr}_{2-\mathrm{x}-\mathrm{y}} \mathrm{Y}_{\mathrm{x}} \mathrm{Ca}_{\mathrm{y}}\left(\mathrm{PO}_{4}\right)_{3}$ 材料の焼結体の相対密度の 組成に対する分布図 ${ }^{13)}$ (出版社より許可を得て掲載) 
ましい物性值である。その観点で, 最適組成は $(\mathrm{Ca}, \mathrm{Y})=(0.13$, 0.07 ) 程度となり，おおよそイオン伝導の結果に対応する值 となった。活性化エネルギーとイオン伝導度の組成に対する 分布はおおよそ一対一対応するような傾向にあるが， Ca を ドープしていない組成では，伝導度が低くなるにもかかわら ず活性化エネルギーが低くなる傾向があるなどの変化もみら れる。これは，Y置換系では低いバルクの活性化エネルギー が報告されている一方, 図 4 に示すように焼結密度が低い結 果も得られていることから, 全導電率は粒界抵抗のために低
くなるが, 活性化エネルギーについてははバルクの結果が反 映したという解釈もできる(詳細は抵抗分離をすることで明 らかになると思われる)。

以上を踏まえて，ここまでに出てきた変数同士の相関を一 挙に示したものが図 7 である。例えばイオン伝導度 (太枠線 内)に注目すると, $\mathrm{Y}$ 濃度, 活性化エネルギー, 相 $(\beta$ 相の割合 $)$ に対しては負の相関があることが分かるが，総じて僅か 7 変 数においても相互の関係は非常に複雑になることが分かる。 今回の結果では, すべての組成組み合わせについて実験デー
(1)

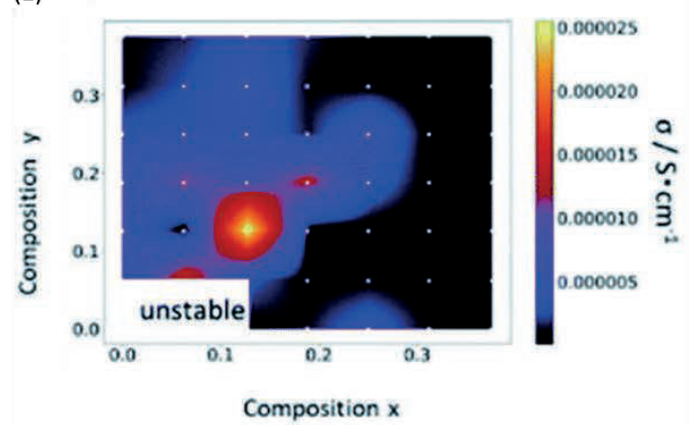

(2)

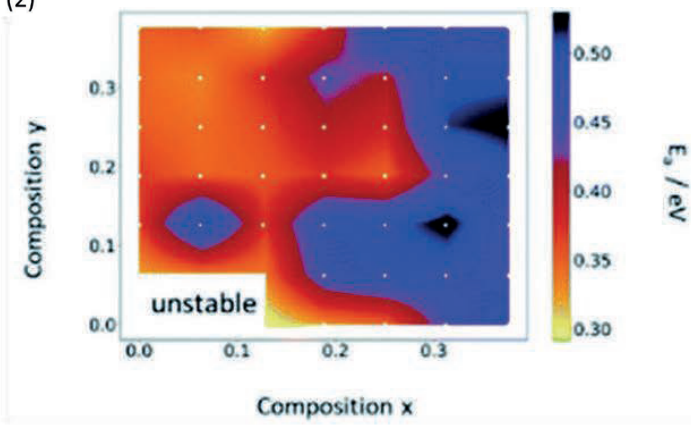

図 $6 \mathrm{AC}$ インピーダンス法で計測した $\mathrm{Li}_{1+\mathrm{x}+2 \mathrm{y}} \mathrm{Zr}_{2-\mathrm{x}-\mathrm{y}} \mathrm{Y}_{\mathrm{x}} \mathrm{Ca}_{\mathrm{y}}\left(\mathrm{PO}_{4}\right)_{3}$ 材料の (1) リチウムイオ ン導電性と (2) その活性化エネルギーの測定結果 ${ }^{13)}$ (出版社より許可を得て掲載)

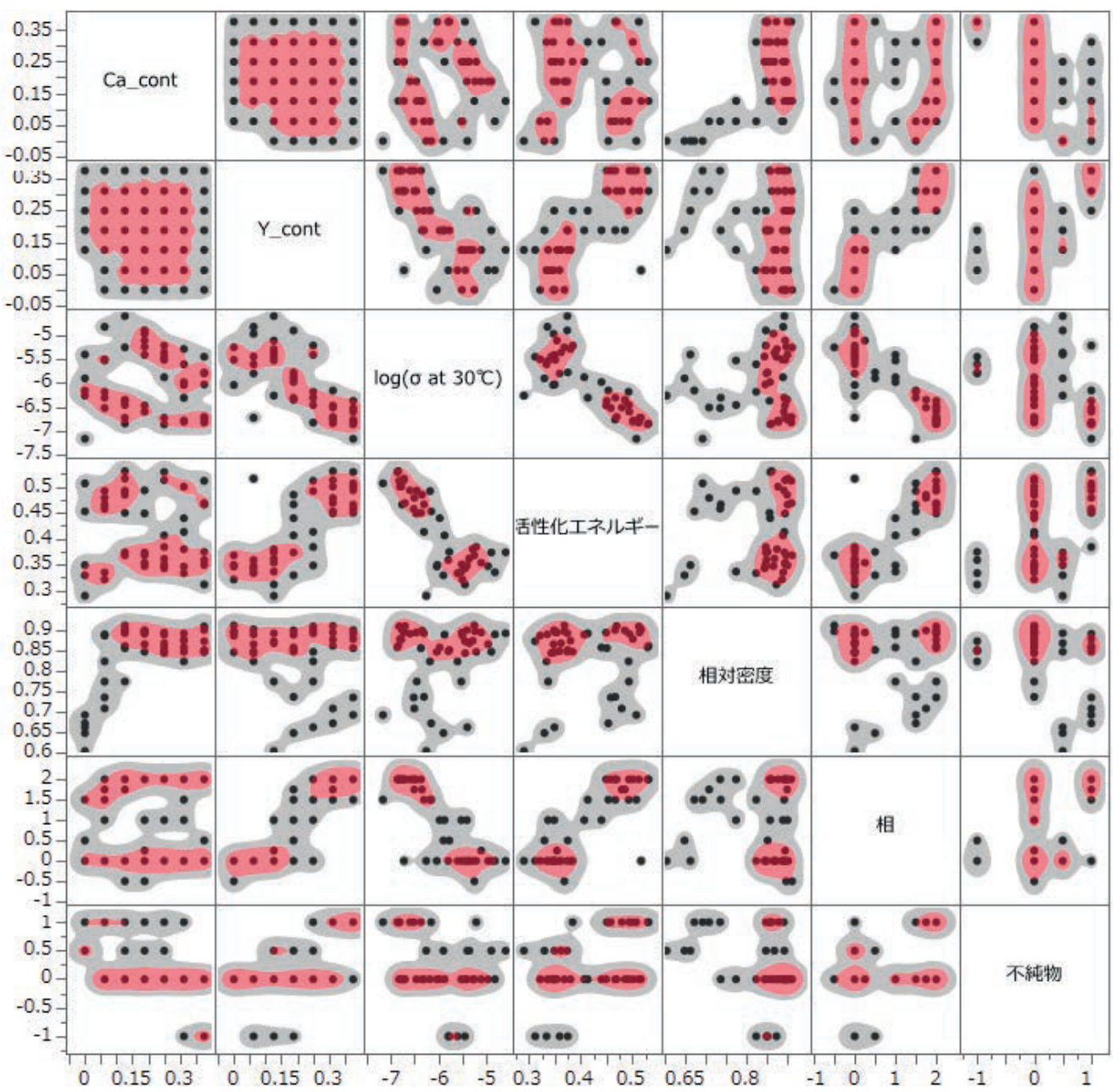

図 $7 \mathrm{Li}_{1+\mathrm{x}+2 \mathrm{y}} \mathrm{Zr}_{2-\mathrm{x}-\mathrm{y}} \mathrm{Y}_{\mathrm{x}} \mathrm{Ca}_{\mathrm{y}}\left(\mathrm{PO}_{4}\right)_{3}$ 材料における組成および実験により計測した值の相関関係図。 灰・桃で塗られている箇所は，測定值のプロットの密集度を示す。 


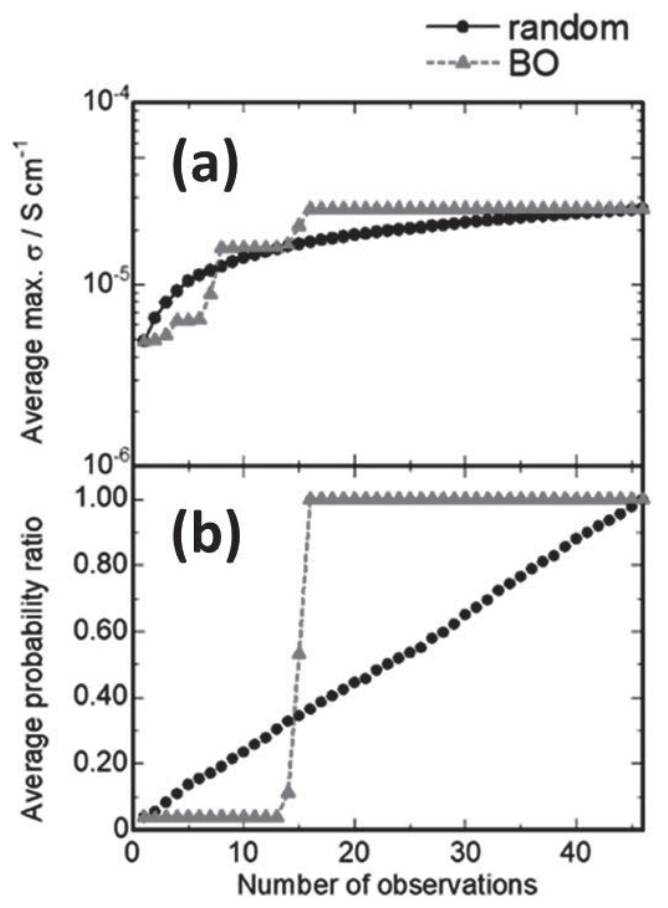

图 $8 \mathrm{Li}_{1+\mathrm{x}+2 \mathrm{y}} \mathrm{Zr}_{2-\mathrm{x}-\mathrm{y}} \mathrm{Y}_{\mathrm{x}} \mathrm{Ca}_{\mathrm{y}}\left(\mathrm{PO}_{4}\right)_{3}$ 材料における $30^{\circ} \mathrm{C}$ リチウ ムイオン導電率のベイズ最適化 $(\mathrm{BO})$ の過程。比較 のためランダムでサンプリングした場合の結果も 併記する。観測回数 (ステップ数)において (a) 最も 高いイオン導電率の推移を示したプロットと (b) 最 大イオン導電性の材料を発見した確率。1000 回の 試行を行っている。 ${ }^{13)}$ (出版社より許可を得て揭載)

夕が表示されているため, デー夕を俯瞰して上述のような傾 向などを議論できるが，実際には逐次的にデータを取得しな ければならず，限られたサンプル数の相関関係を眺めながら, いち早く最適值の目星を得なければならない。（できるだけ， 少ないサンプル数で最適解を発見することが望ましい。）

以上のように Ca と Y をコドープした LZP系材料につい て組成網羅的に実験評価した結果を眺めることで, 複雑な組 成と構造・組織・物性の関係が明らかとなった。このような 材料の組成空間に対して, AI たるベイズ最適化アルゴリズ ムが，イオン伝導性が最も高くなる最適組成を「効率的」に 発見できるのか検討した。なお，探索対象となる組成のデー 夕については全て調査している状況にあり最適解は既知の状 態である。これからの検討は, コンピューター $(\mathrm{AI})$ には, 意 図的の全ての回答を伏せておき, AI が提案する通りにサン プリングを行い，あらかじめ調査した結果 $(\mathrm{AI}$ が指定した組 成のイオン導電性)を AI に伝える(答え合わせ)という方法 である。AI は手持ちのデータで学習し, 次に探索すべき組 成を「搾取」と「探索」の二つのアルゴリズムにて提案する。 この提案と答え合わせのループを何回繰り返せば最適組成に なるかを検討する。また，第一ステップにおけるサンプリン グは 2 組成のサンプルをランダム選択とした。このような手 順 $($ ループ)を 1000 回繰り返し, 発見率の平均化処理を実施

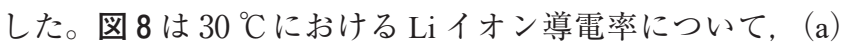
進渉ステップにおいて発見された最も高いイオン導電率値と (b) 最適組成のステップ数に対する発見確率をプロットした 図である。比較のため, ランダムサンプリングをした場合の
結果 (1000 回平均) も示した。図 8 (a)に示されるように, 調 査した材料の最大イオン導電率はステップとともに増加して いくが, ごく初期にはランダム探査の方が成果は上回ってい る。またランダム探査では，連続関数のような振る舞いが見 られた。一方べイズ最適化で探索していく場合には，発見し た最高イオン導電率が，ところどころ急激に増加するような 不連続的な傾向がみられた。はっきりと言明することはでき ないが,「探索」から「搾取」を優先するような変化があっ たように見られる。パネル (b) の最適組成発見率の結果は, 上記の傾向がさらに極端に表れている。ランダム探索におけ る発見率は比例関数になる(例えば, 全体の半分を探索すれば, $50 \%$ の発見率になる)。一方べイズ最適化探索では, 最初の 13 ステップ間, 数 \%の発見率で一定だったものが, 14 ステッ プ目以降急激に増大し，16 ステップ目では $100 \%$ の発見率 となった(1000回の試行結果であることを考慮すると 99.9\%)。このような結果から, 今回適用した EI 戦略に基づ くベイズ最適化では, 初期は意図的に組成全体を俯瞰するよ うにデータをサンプリングする「探索」が行われる（実際には， 予測值の分散が大きい箇所を優先してサンプリングしてい る)。その後, 組成空間に対するイオン導電性の分布の不明 瞭な箇所がなくなると, 予測值の最も高い箇所を優先して調 べる「搾取」が行われていることを示している。今回の結果 が全 47 組成の探索空間に対して 16 ステップで優れた材料を 発見できることが分かったので，探索効率は 47/16，すなわ ち〜 3 倍と言える。このような結果から, ベイズ最適化を用 いれば，コドープして探索空間が拡大した材料においても， 多不必要なデー夕を取らずに短いステップ数で最適組成を得 られることが実証された。この例では, 網羅的サンプリング したデータベースをもとにベイズ最適化の効率性を定量的検 証するという目的があったために，コドープ系を対象とした 僅か 50 件程度の比較的簡単なデー夕に対する最適化である ため, ベイズ最適化の効率化も 3 倍程度であった。比較は困 難であるが, 訓練を受けた材料研究者であれば, AI に頼ら ずとも同等程度の効率化は果たせると思われる。しかし先述 したように 3 元素, 4 元素ドープや, 合成条件・焼結条件を 増やし探索空間を指数関数的に拡大すると, 人間のデー夕俯 㒈力, 判断力の能力的限界に近づくと思われ, 有効なアプロー チになりうる。また, 今回は組成 $(\mathrm{Ca} / \mathrm{Y}$ ドープ量)のみを記 述子(イオン導電性を予測するための変数) として採用したが, 適切な記述子の追加は効率向上につながる。最近, 我々は計 算デー夕をもとに実施した組成最適化を実施し, 組成以外の 記述子を追加することで約 170 サンプルの材料物性最適化を， ランダム探索に対して 20 倍 (90\% 正解率) という高い効率で 発見できることを示した ${ }^{14)}$ 。

また，データセットの工夫だけではなく, ベイズ最適化の アルゴリズムそのもの, あるいは周辺的な技術との連携によ り発展的な利用法がある。例えば多目的最適化と呼ばれるも のは, 複数の目的関数 (最適化のターゲットとする值：イオ ン導電率など)の最適化に用いることができる。具体的には, イオン導電性と焼結密度(材料の機械特性)を両立した材料を 開発したい場合には，どちらの值も高くなるような材料を探 す必要がある。現実にはトレードオフ(片方の物性が高くな 
ると, もう一方の性能が劣化する) 現象が発生することがま まあるため, パレート最適解と呼ばれる候補材リストを, 多 目的最適化では評価することになる。パレート最適解を構成 する材料については, 注目している複数の性能を同時に取り 換えできないような材料の一群を指す。このようなパレート 最適解全体を, ベイズ最適化で効率よく探索することも可能 である。条件設定が複雑なため, 50 サンプル程度では多目 的最適化の効率はほとんど向上しないが，仮想的に組成を 225 組み合わせに拡張した系に対しては，100 サンプル以下 でパレート最適解の組み合わせを得ることに成功している (探索効率：ランダム探索に対して 2.5 倍程度)。

最後に転移学習を活用した応用も考えられる。EI 戦略を 用いたベイズ最適化では, 最初は「探索」をして与えた記述 子と目的関数(イオン導電性など)の関係性を学習する必要が ある。仮に似たような系 (たとえば $\mathrm{Sr}$ と Y をコドープする

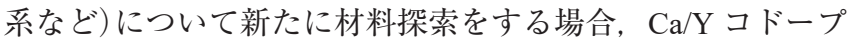
系で得られた知識が役に立つと思われる。これをべイズ最適 化でも応用することは可能である。詳細は割愛するが, 我々 の以前の研究でも 150 サンプルのリチウムイオン導電性酸化 物についてベイズ最適化を行った後, $\mathrm{Li}$ を $\mathrm{Na}$ に置き換えて $\mathrm{Na}$ イオン導電性の最適化を行った ${ }^{15)}$ 。その際 Li イオン導電 性材料探索で得られたパラメーターを $\mathrm{Na}$ イオン導電性のベ イズ最適化に継承させたところ(転移学習)，「探索」に必要 な期間を大幅に減らし，効率よく最適材料を発見することに 成功している。現実の実験による材料最適化にも活用できる テクニックと言える。これらのベイズ最適化を中心とした技 術を駆使して, 従来では手のつけようもなかった複雑組成, 複雑プロセスを研究開発段階で取り扱えるようなスキームが 構築できるかもしれない。冒頭でも述べたように蓄電池の研 究者が数十年かけて $\mathrm{LiCoO}_{2}$ を骨格とし, 遷移金属 $\mathrm{Co}$ の組 成複雑化を成し遂げてきた過程を，大幅に短縮する可能性を 秘めているかもしれない。

\section{5. 今後の展望}

本稿冒頭で，今後の材料インフォマティクスにおいて，実 験とインフォマティクスの連携の重要性について指摘した。

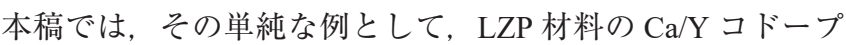
による材料物性改善を Bayes 最適化で実施した例を述べた。 インフォマティクスで取り扱う題材としては非常に小規模の 50 サンプル程度であっても, また, 非常に複雑な物性・組織・ 構造の分布を示す材料であっても，ランダム探索に対して約 3 倍の効率化がなされた。今後は，人間が取り扱えないよう なより複雑な系に対しての実例研究が必要であろう。類似の 実験操作を大量に実施する必要があるため, ラボオートメー ションによる実験作業の自動化などがなされると望ましいだ
ろう。また，単に組成のみだけではなく，合成法などのプロ セッシングも含めた効率的最適化が求められる。一方, 今回 提示した研究例では, 記述子に単純な組成量のみを用いてい るが, より効率的な最適化プロセスの実現のために有用な記 述子開発も求められる。記述子の開発について, 例えば, 材 料計算との連携する余地があるように思える。このような課 題を解決しつつ, 産業的に直接役立つような事例を積み上げ ていくことが重要であると考えている。

\section{謝 辞}

本研究の一部は文部科学省「元素戦略プロジェクト研究拠 点形成型 京都大学 ESICB」(JPMXP0112101003), 科学技術 振興機構 (JST)「情報統合型物質・材料開発イニシアティブ (MI2I)」および「先端的低炭素化技術開発事業 $($ ALCA)」 (JPMJAL1301)，科研費 (18H01707，19H05815，20H02436) の委託・助成により実施された。また，これらの成果は研究 室の学生と取り組みと, 多くの共同研究者と関係企業のご協 力により得られたものです。この場をかりて関係各位に感謝 の意を表します。

(Received November 17, 2020)

\section{文献}

1) J. Gray ; J. ACM, 50, 41 (2003).

2 ) K. Rajan ; Mat. Today, 8, 38 (2005).

3 ) K. Mizushima, P. C. Jones, P. J. Wiseman, J. B. Goodenough ; Mat. Res. Bull., 15, 783 (1980).

4 ) J. Mockus ; Optimization Techniques IFIP Technical Conference, 400 (1974)

5 ) 中山将伸, 中野高毅; 電気化学, 88, 21 (2020).

6 ) R. Murugan, V. Thangadurai, W. Weppner ; Angew. Chemie, Int. Ed., 46, 7778 (2007).

7 ) H. Xie, J. B. Goodenough, Y. Li ; J. Power Sources, 196, 7760 (2011).

$8)$ Y. Li, W. Zhou, X. Chen, X. Lu, Z. Cui, S. Xin, L. Xue, Q. Jia, J. B. Goodenough; Proc. Natil. Acad. Sci. U. S. A., 113, 13313 (2016).

9 ) Y. Noda, K. Nakano, H. Takeda, M. Kotobuki, L. Lu, M. Nakayama ; Chem. Mater., 29, 8983 (2017).

10) H. Xie, Y. Li, J. B. Goodenough ; RSC Adv., 1, 1728 (2011).

11) Y. Li, M. Liu, K. Liu, C. A. Wang; J. Power Sources, 240, 50 (2013).

12) S. Theodoridis ; Machine Learning: A Bayesian and Optimization Perspective, p.58 (Academic Press, 2015).

13) M. Harada, H. Takeda, S. Suzuki, K. Nakano, N. Tanibata, M. Nakayama, M. Karasuyama, I. Takeuchi ; J. Mater. Chem., 8, 15103 (2020).

14) K. Nakano, Y. Noda, N. Tanibata, H. Takeda, M. Nakayama, R. Kobayashi, I. Takeuchi ; APL Materials, 8, 041112 (2020).

15) R. Jalem, K. Kanamori, I. Takeuchi, M. Nakayama, H. Yamasaki, T. Saito ; Sci. Rep. 8, 5845 (2018). 